\title{
МОНГОЛ, ОРОСЫН СТРАТЕГИЙН ТУНШЛЭЛИЙГ БАТАЛГААЖУУЛАХ АЛХМУУД
}

\section{Товч утra:}

К.Дэмбэрэл*

Энэхуу судалгааны материал нь 1991 оноос хойш Монгол, Оросын хооронд байгуупсан өндөр ач холбогдол бүхий 4 чухал баримт бичгүүдийг зүйл бүрээр задалж үзсэн. Эдгээр нь 1991 оны Найрамдал, хамтын ажиппагааны Тунхагпал, 1993 оны Монгол, Оросын найрамдлын Гэрээ, 2000 оны Улаанбаатарын Тунхаглал, 2006 оны Москвагийн Тунхагпалууд бипээ. Энэ судалгаа нь баримт бичгүүдийг байгуупах үеийн хоёр орны дотоод эдийн засаг, упс төрийн нөхцөл байдлыг товч харьуупан үзүүпсэн. Монгол, Оросын стратегийн түншлэлд чухал ач холбогдол бухий эдгээр баримт бичгуүдийн талаар судпаачийн үнэлэлт, дүгнэлт гаргасан судапгааны ажил болно.

Түпхүүр үгс -"Найрамдал, хамтын ажилиагааны Тунхагпап", "Найрамдал, хамтын ажиплагааны Гэрээ", Монгол Улс, Оросын Холбооны Улс, "Улаанбаатарын тунхаглал", “Москвагийн тунхаглап"

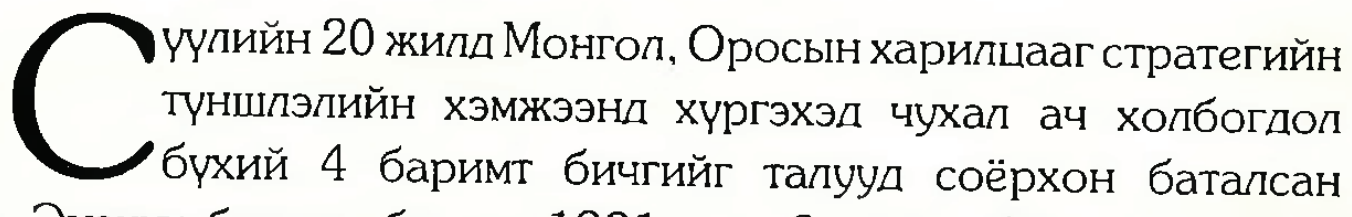
билээ. Энэхуу баримт бичигт 1991 оны 2 сарын 12-нд үзэгпэсэн БНМАУ, ЗСБНХОУ-ын хоорондын хамтын ажиплагаа, сайн хөршийн тухай Тунхаглал, 1993 оны 1 сарын 20-нд байгуулсан Монгол улс, ОХУ-ын хоорондын найрамдалт харилцаа, хамтын ажиппагааны тухай Гэрээ, 2000 оны 11 сарын 13-нд байгуупсан Улаанбаатарын Тунхаглал, 2006 оны 12 сарын 8-нд байгуулсан Москвагийн Тунхаглал багтдаг. Эдгээn нь хоёр орны харипцааны

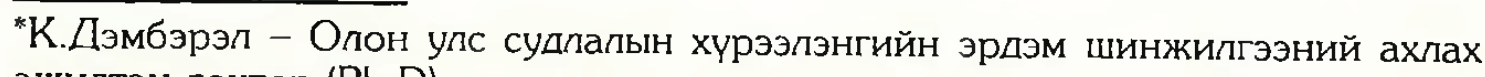
ажилтан доктор (Ph.D) 
үндсэн баримт бичиг төдийгүй стратегийн түншлэлийг тунхагласан баримт бичиг тул тус бүрд нь зүйл нь бүр чухал, тиймээс зүйл бүрээр нь залалж үзэх нь судпаачдын үүрэг билээ.

Энэ өгүүпэл нь сүүпийн 20 гаруй жилд хоёр упсын хооронд дээд хэмжээний уупзалтын уеэр байгуупсан "нэн" чухал баримт бичгуүдийг үзэглэх уеийн хоёр орны упс төр, нийгэм эдийн засгийн ерөнхий төлөвийг тоймпон, чухам ямар нөхцөпд баримт бичгүуд маань баталгаажсаныг үзуүпэх зорилготой судалгааны материал бөлгөө.

Аливаа гэрээ, хэлэлцээр нь тухайн асуудлыг хууль эрхийн хүрээнд баталгаажуупж буй зүйл. Монгол-Оросын харипцааны хувьд боп өнгөрсөн зуунд дээд хэмжээнд нэлээн олон тооны гэрээг байгуулсан. Эдгээр гэрээнууд нь тухайн уеийн упс төр, нийгэм эдийн засгийн шаардлагаар бий болж байсан. Манай судлаачид алив нэг гэрээг байгуулангуут харипцаа шинэ шатанд гарлаа хэмээн ойлгож, бичиж ирсэн. Энэхуу өгүулэлд хоёр орны харилцааг уламжлалт байдпаар бус арай өөр өнцгөөс харуупахыг зорилоо.

Олон упсын хоорондын хууль эрхзуйн баримт бичигт улсуудын бие даасан тэгш байдал, хүч үп хэрэглэх ба хүчээр түрэмгийлэхгүй байх, газар нутгийн бүрэн бүтэн байдал, хил хязгаарын бүрэн бүтэн байдал, маргааныг энхийн замаар зохицуупах, дотоод хэрэгт үп оролцох, хуний эрх, үндсэн эрх чөлөөг хүндэтгэх, ард иргэд нь өөрсдийн хувь заяанд эзэн болох, улс хоорондын хамтын ажиплагааны тухай, олон улсад хүпээсэн үүргээ чин шударгаар биепуүпэх гэсэн 10 зарчмыг мөрдиөг болгодог.

Шинэ уеийн харилцааны үндсэн 4 чухал баримт бичигт энэхуу 10 зарчим бурэн дуүрэн тусгагдаж, хоёр орны харипцааны онциогуудыг тодруупж өгсөн. Ингээд баримт бичгүудийг тус бурээр авч үзье.

\section{1991 оны Тунхагпал нь шинэ уеийн харилцааны эхпэпийн баримт бичиг болох нь}

1991 оны "Бүгд Найрамлах Монгол Ард Упс, Зөвлөлт Социалист Бугд Найрамдах Холбоот Орос Упсын найрамдал, сайн хөршийн хамтын ажиплагааны тухай Тунхагпал"-ын хувьд гэвэл хоёр орны улс төрийн нөхцөл байдал харьцангуй өөр, нийгэм, эдийн засгийн нөхцөл байдал ижил төстэй байсан хэмээн үзэж болно. Тиймээс харьцангуй өөр нөхцөпц байсан упс төрийн байдлыг тус тусал авч үзвэл дараах дүр зураг харагдаж байна.

Энэхуу Тунхаглалыг хоёр улсын Засгийн газрын тэргүүн нар үзэглэсэн. Өөрөөр хэлбэл, хоёр улсын Гүйцэтгэх засаглалын тэргүүн нарын хэмжээнд гэсэн үг. 


\section{БНМАУ-ын дотоод улс төрийн нөхцоп байдап}

Тунхагпалд гарын үсэг зурсан нэг тал болох БНМАУ нь энэ уед төрийн эрх барих дээд байгууппага болох Ардын Их Хурал (нийт 430 депутаттай парпаментын дээд танхим, үунээс МАХН гишүун 357 буюу 84\%, АН гишүун 16 буюу 3,8\%, МҮДН гишүун 6 буюу 1,4\%, МСДН гишүун 4 буюу 1\%, 36 нам бусчууд, МХЗЭ гишүун 9) ${ }^{1}$, түунээс сонгогдсон Ерөнхийлөгч (МАХН-аас нэрийг дэвшуүпж гаргасан П.Очирбат), Упсын Бага Хурап (нийт 54 гишүүн байснаас, 4 гишүун өөр ажилд томилогдсон тул тэдний эрхийг тудгэлзуулж 50 гишуунтэйгээр үйл ажиплагаагаа явуулж байсан, МАХН-31, АН-13, МҮДН-3, МСДН-3 төлөөлөптэй байсан, байнгын ажилпагаатай, парламентын доод танхим, дарга буюу дэд ерөнхийлөгч Р.Гончигдорж-МСДН), Эвспийн засгийн газар (Засгийн газрын тэргуун Д.Бямбасүрэн-МАХН, тэргуун шадар сайд Д.Ганболд-МҮДН, шадар сайд Д.Дорлигжав-АН, шадар сайд Ч.Пүрэвдорж-МАХН, нийт 12 яамтай, 16 гишүунтэй Эвспийн засгийн газар байсан) ${ }^{2}$. БНМАУ-ын Галаад харилцааны сайдаар УБХ-аас 59,2\%-ийн санапаар дэмжигдсэн Ц.Гомбосурэн ажилпаж байлаа.

Упсын Бага Хурлын 2-р чуулганаар П.Очирбат тэргүүтэй шинэ үндсэн хууль боловсруулах ажлын комиссыг байгуулан ажилд нь оруупсан уе байлаа. БНМАУ-ын хувьд улс төрийн өөрчлөлт 1990 оны 3, 4 сараас идэвхтэй хэлэпцэгдэж мөн оны 5 сард хурапдсан АИХ-ын 9-р чуупганаар улс төрийн нэлээн олон шинэчлэпийг хийсэн. Тиймээс 1991 оны БНМАУ, ЗСБНХОУ-ын хоорондын сайн хөрш, найрамдал хамтын ажиллагааны Тунхаглал зурагдах мөчид шинэ Үндсэн хуулийн хэлэлцүупэг ид явагдаж бүхэлдээ Монгол упсын хувьд улс төрийн тогтолцооны "шилжилтийн үе" байлаа. Өөрөөр хэлбэл, шинэ үндсэн хуупиа баталж амжаагүй, олон намын тогтолцоонд шилжсэн, эвспийн засгийн газар үйл ажиллагаа явуулж байсан ийм цаг мөчид энэ хамтын ажилпагааны тунхагпап зурагдсан билээ.

\section{РСФСР-ын дотоод улс төрийн нөхцөп байдал}

Тунхагпалд гарын усэг зурсан нөгөө тал болох РСФСР буюу ЗСБНХОУ-ын хувьд бол энэ цаг мөчид ЗХУ-ын бурэлдэхуүнд багтсан хэвээр байсан хэдий ч Зөвлөлт Холбоот Улсад задрал явагдаад эхэлчихсэн ба тухайн үеийн удирдлагын зугээс ямар нэг хэлбэрээр авч үлдэх арга саам эрэлхийлж байсан уе байв. ЗСБНХОУ-ын Дээд Зөвлөлийн дарга Б.Ельцин, ЗХУ-ын анхны бөгөөд эцсийн Ерөнхийлөгч М.Горбачёв нарын хооронд ЗХУ-ын “субъектуудын” 
асуудлаарх тэмцэл ширууссэн цаг мөч байсан. Өөрөөр хэлбэл, ЗХУ-ын задралын процесс нь “шинэчпэгдсэн хопбооны" гэрээнээс хамаарахаар болсон үе байлаа.

Хамтын ажиллагааны Тунхаглал зурагдах мөчид буюу 2 сард Хойд хөршид маань “шинэчлэгдсэн ЗХУ"-ыг бүрэн бүтэн байлгах, ЗСБНХОУ-д ерөнхийлөгчийн албан тушаал бий болгох зэрэг асуудпуудаар бүх нийтийн санал асуупга явуулах компанит ажлын бэлтгэл ид явагдаж байлаа.

\section{Тунхаглалын онциог бөгөөд чухап талууд}

1991 оны Тунхагпалаар хоёр упсын субъект хооронд хамтын ажилпагааг эхлуүлсэн. Энэ нь аймаг, муж, сум нэгдэл, үйлдвэр аж ахуйн газрын хүрээнд хэмээн тунхагласан. Тунхаглалд дамжин өнгөрех тээврийн асуудлыг зохион байгуулах талаар анхлан тусгасан.

Түүнчпэн Тунхагпалд тусгасан чухал зүйлийн нэг нь залуу үеийнхэнд хоёр талын харипцааг ойлгуупах үүднээс залуучуудын байгууплагын хамтын ажиппагааг тал бүрээр дэмжихээ хоёр тап илэрхийлсэн ба сургуупиудын харилцааг ч өргөжүүлэхийг зүйтэй гэж үзсэн. Хоёр парламент болон сонгуульт байгууплагуудын хамтын ажиппагааг хөгжүупэхээ анхлан тунхагласан.

Уг Тунхаглапд хоёр талын Галаад хэргийн сайд нарыг жилд нэгээс доошгүй уупзаж байхыг Тунхагпасан байдаг. Хоёр упсын иргэдийн харилцан зорчих асуудлыг хөнгөвчлех тал дээр санаачилга гаргахаа хоёр тал тунхагпасан.

Худалдаа, эдийн засгийн хамтын ажиллагаанд гарч болох асуудлыг шийдвэрлуүпэх зорилгоор хоёр талын холимог комисс байгуулан ажилпуупна хэмээн тунхагпасан. Энэхуу Тунхаглал нь хоёр улсын хооронд байгуупах бусад баримт бичгийн үзэл санааны эх хэмээн заажээ.

1991 оны найрамдал хамтын ажиллагааны Тунхагпал нь ОХУын хувьд Азийн упс орнуудтай байгуупсан анхны агуулга, зорилгын хувьд шинэ баримт бичиг байлаа.

Монгол улсын хувьд хойд хөршөөс ямар нэг хамааралгүйгээр үндэсний сонирхлын дагуу бие даасан бодпого явуупах “допуск-тай болсноо энэхуү баримт бичгээр баталгаажуулсан ба Оросын зугээс ч “бид цаашид танай дотоод, гадаад асуудалд оропцохгүй" гэдгээ баталгаажуулпаа. Гэхдээ талууд түухэн харилцаагаа үнэлээд, цаашил харипцан ашигтай хамтран ажиплахаа тунхагласан явдал "далан жипийн холбоотон нэг гэр бүп" байсан хоёр упсыг "соёлтойгоор гэр бүпээ цуциуупсан" үйл хэрэг байлаа. 


\subsection{3 оны Монгол, Оросын “Найрамдапт харипиаа, хамтын ажиплагааны тухай гэрээ”}

1993 оны 1 сарын 20-нд Монгоп упсын Ерөнхийлөгчийн ОХУ-д хийсэн төрийн айлчпалын үеэр Монгол, Орос улсын хооронд байгуулсан "Найрамдалт харипцаа, хамтын ажилпагааны тухай Гэрээ”-г ОХУ-ын Дээд Зөвлөлийн 1993 оны 6 сарын 3-ны N 51001 тоот тогтоолоор соёрхон баталснаар хоёр улсын харипцааны баримт бичиг хүчин төгөлдөр бопж үйлчилж эхэлсэн.

1993 оны хоёр талын хамтын ажилпагааны тухайн гэрээний үндсэн ЗСБНХОУ, БНМАУ-ын хооронд 1991 оны 2 сарын 12 байгуупсан Сайн хөрш, найрамдал хамтын ажилпагааны тухай Тунхаглап хэмээн талууд Гэрээний оршилд заасан ба 1921 оны Монгол-Оросын найрамдлын гэрээг хоёр тал өндөр үнэлсэн ${ }^{3}$ байлаа.

Энэ гэрээ нь ОХУ, Монгол улсын төрийн тэргуүний хэмжээнд байгуулсан анхны гэрээ байж, хоёр улсын харипцааг шинэ цаг үед явуупах баримт бичиг болсон. Хэдийгээр энэхуү гэрээ нь ОХУ-ын шинэ Үндсэн хуупь батпагдаагуй зөвлөлт маягийн үндсэн хуупьтай байсан ч, Монголын шинэ Үндсэн хууль батлагдаад нэг жилийн нуүр үзсэн үед байгуупагдсан. Түүнчпэн хоёр улсын хоорондын Найрамдал хамтын ажиппагааны 1966 оны гэрээнээс 27 жилийн дараа байгуулсан агуупгын хувьд "асар" өөр шинжтэй гэрээ байлаа.

1993 онд Монгол-Оросын хооронд байгуупсан гэрээг уламжлалт байдлаар үзвэл хоёр орны харилцаа чанарын шинэ түвшинд гарлаа гэж үзэх үндэстэй. Үнэн хэрэгтээ гэрээ байгуулсан уеэс хойш бараг 10 шахам жилд бид энэ "шинэ түвшинг" мэдрээгүй гэж хэлж болно. Өөрөөр хэлбэл, чухам энэ үед хоёр талын харилцаа зогсонги байдалтай байсан. Зогсонги гэдэг нь урьдын далайцтай уетэй харьцуулахад шүу дээ. Оросын зүгээс монгол руу, ази руу хандлагаа супруулсан 10 орчим жил нь Монголын хувьд эерэг үр дагавартай байсан хэмээн дүгнэх боломжийг ч бас өгч байна.

1993 оны Гэрээ нь 20 жилийн хугацаанд байгуулагдсан бөгөөд цаашид 5, 5 жилээр сунгагдах боломжтой хэмээн заасан.

Ингээд гэрээ байгуупагдах уеийн Монголын улс төрийн нөхцөл байдлын талаар товч сийрүүпье.

\section{Монгол улсын дотоод упс төрийн нөхцөп байдал}

1992 оны 1 сарын 13̈-нд Монгол упсын шинэ Үндсэн хууль батлагдлаа. Ингэснээр БНМАУ нь Монгол улс хэмээн нэрлэгдэж парламентын БНУ болсон. Төрийн эрх барих дээд байгууплага нь 76 гишүун бүхий УИХ байх бөгөөд тэндээс олонхийн суудал бүхий улс 
төрийн хүчин Засгийн газраа санаачпан байгуупахаар хуульчилсан. 1992 оны хавар анхны сонгуупийг зохион байгуулж УИХ-ыг сонгосон. Энэ сонгуульд МАХН үнэмпэхүй ялалт байгуулсан. Тэд 76 суудлын 70-ыг нь авсан бол сөрөг хүчин 5 суудаптай (МСДН - 1, МоАН, Нэгдсэн Нам, МҮДН-ын эвсэл-4) $)^{4}$ байсан. Бие даан нэр дэвшиж сонгогдсон Гэндэнсамбуугийн Зуунай нь МАХН-ын гишүун юм. Уг сонгууль нь томсгосон мажоритар системээр буюу, аймаг, дүүргуүдийг тус бурийг нэг тойрог болгон, тойрог тус бүрээс 2-4 хүн сонгогдож байв. УИХ-д олонхийн суудал авсан МАХН дангаар Засгийн газраа байгуупсан. Засгийн газрын тэргүун Ерөнхий сайдаар П.Жасрай томипогдсон. Монгоп упсын шинэ үндсэн хуупийн хүрээнд Монгоп упсын Ерөнхийлөгчийн үүрэгт ажлыг П.Очирбат 1992 оны 2 сарын 12-ноос 1993 оны 6 сар хүртэл хашсан ба 1993 оны Ерөнхийлөгчийн сонгуупиар МСДН-аас нэр дэвшин ялалт байгуупж хоёрдахь бүрэн эрх нь хэрэгжсэн.

\section{ОХУ-ын дотоод упс төрийн нөхцөп байдал}

1991 оны 12 сарын 25-нд 3ХУ оршин тогтнохоо больсон. ОХУ нь ЗХУ-ыг НҮБ-д төлөөлөх зэрэг түуний бухий п “Үүрэг, хариуцпагыг" авч упдиээ.

1991 оны 6 сард Б.Ельцин бүх нийтийн санал хураалтаар 57\%-ийн санал авч ОХУ-ын ерөнхийлөгчөер сонгогдсон ба 1992 оны туршид үндсэн хуупийн зөрчил шируүсч Орост "хоёр засаглал" тогтсон ${ }^{5}$ байпаа.

1993 оны 10 сард дэд ерөнхийлөгч А.Рушкойн бурэн эрхийг зогсоож, парламент буюу Дээд Зөвлөлөө тараасан нь хууль зүйн хувьд апдаатай байсан хэдий ч өөрчлөлт, шинэчлэлт, ардчиплыг урагшлуулах алхам байлаа хэмээн улс төр судлаачид дүгнэж байдаг. Ерөнхийлөгч Б.Ельциний энэ алхмыг Өрнөдөд дэмжсэн маягаар өнгөрөөсөн. Дээд Зөвлөлөө цэргийн хүчээр тарааж, түүний спикер Р.Хасбулатов, дэд ерөнхийпөгч А.Руцкой нарын талынхныг "Пефортов"-т суупгахад армийн дээд удирдлагын дор хаяад $2 / 3$ нь Б.Ельциний талд байсан явдал нөлөөлсөн.

1993 оны 12 сарын 12-нд батпагдсан ОХУ-ын шинэ үндсэн хуупьд Ерөнхийлөгчийн засагпаптай, хоёр танхим бүхий парпаментгай, холбооны БНУ хэмээн тунхагпасан. УГ үндсэн хуупиар түунд засвар оруупах, зарим зүйлийг эргэн харах тухай саналыг Ерөнхийлөгч, Холбооны Зөвпөл, Төрийн Дум, Засгийн газар, ОХУ-ын субъектуудын хуупь тогтоох байгууппагууд, түүнчлэн Холбооны Зөвлөл, Төрийн Думын депутатуудын 1/5 -ээс багагуй тоотой депутатын бүпэг санал оруупах эрхтэй болсон. 


\section{3 оны Гэрээний агуупгыг нягталбал}

Энэхуү гэрээ нь аливаа нэгүзэл суртлаас ангид байж бие биеийн хусэл эрмэпзпийг хүндэтгэн үзэх агуупга бүхий Монгол, Оросын хоорондын анхны гэрээ байсан. Уг хорин зүйл бүхий гэрээний 1 , 2-р зүйлд нийтпэг харипцааны асуудап тусгагдсан ба 4, 5, 6, 7-p зүйлд улс төрийн болон олон улсын улс төрийн харилцааны талаар тунхагласан. Гэрээний $8,9,10,11,12,13,14,15-р$ зүйлүүдэд хоёр орны хоорондын харилцааны бүхий $л$ салбарын асуудлыг багтаажээ. Шинэ гэрээний шинэлэг нэг зүйл бол 3-р заалт буюу хоёр орны парламент болон сонгуульт байгууплагуудын хамтын ажилпагааг эхлуүпэн хөгжүүпэхийг тусгасан явдал. Гэрээнд түгээмэл асуудлаас гадна шинэ нөхцөл байдапд зохицуупан тусгасан хэд хэдэн заалтууд байгаа билээ. Тухайлбал, дор дурдсан зүйлуүдийг цаашдын гэрээ, хэлэлцээр анхаарч хадгапж явах чухал тул тусгайлан энд өгүүпж байна.

1993 оны гэрээнд хоёр тал бие биений эсрэг чигпэсэн цэрэгулс төрийн эвсэлд үп нэгдэх, ийм утгатай аливаа гэрээ хэлэлцээрийг гуравдагч улстай байгуулахгүй байх талаар тохирсон. Түунчлэн гэрээ нь анх удаа хоёр орны хоорондын холбоотны асуудлыг үгүй хийсэн.

Гэрээгээр Монгол упсыг Ази Номхон далайн бүс нуггийн улс хэмээн ОХУ зөвшөөрөн энэ бүс нутаг хоёр болон олон талын хамтын ажиппагааг хөгжуупэхийг чухапчилсан байдаг. Гэрээнд "аль нэг талын аюулгүй байдлын асуудалд заналхийлж болзошгүй гэж үзвэл харилцан зөвлөпдөнө"6 хэмээн тусгажээ.

Гурван талын хөрөнгө оруулалт бүхий хамтын ажиппагааг дэмжихээ энд дахин нотолсон байна.

ОХУ-ын шинжпэх ухааны сапбартай, нэн япангуяа суурь судалгаан дээр хамтран ажиппах талаарх нөхциийг бурдуүпнэ хэмээн заасан байгааг Монголын тал бүрэн дүүрэн ашиглах ёстой.

Хоёр улсын хоорондын гэрээнд гарын үсэг зурсан анхны Ерөнхийлөгчдийн хувьд ижил төстэй зүйлуүд олон бий. Тухайлбал, БНМАУ-ын АИХ-ын Тэргүупэгцдй̆н дарга П.Очирбат нь МАХН-аас Ерөнхийлөгчийн суудалд суусан ба ЗСБНХОУ-ын Дээд Зөвлөлийн дарга Б.Ельцин нь тухайн үедээ ЗХУКН-ын ТХ-ны УТТ-ны гишүүн, Москва хотын Намын хорооны дарга ч байсан. Энэ албан тушаалаасаа хоёупаа Ерөнхийлөгчид дэвшсэн төдийгүй хоёул өөрчлөлт, шинэчлэл, ардчиплыг дэмжиж ажипласан шипжилтийн үеийн төрийн тэргүүнуүд байлаа. Хоёул 1990 оны хавар 5 сард АИХ, Д3-ийн даргад дэвшин ажиллаж байгаад Ерөнхийлөгчид нэр дэвшин сонгогдсон төрийн ажлын ихээхэн туршиагатай хүмүус байсан. 


\section{3. Упаанбаатарын Тунхагпап}

Улаанбаатарын тунхаглал нь 1993 оны найрамдал, хамтын ажиппагааны гэрээнд талууд үнэнч байгаа гэдгээ батпан харуупсан төдийгүй цаашид тапуудын хамтран ажиллах чиглэлуүдийг улам тодруупсан баримт бичиг байлаа.

Улаанбаатарын тунхаглалыг гаргаснаар Монгол улс, Оросын Холбооны улсын хоорондын харипцаанд чухал үйл явдал болсон гэдэгт талууд итгэлтэй байгаа. Хойд хөршийн төрийн тэргуүн Монгол упсын Ерөнхийлөгчийн урипгаар 2000 оны 11 сарын 1314-нд Улаанбаатар хотноо 27 жилийн дараа Монгоп улсад дээд хэмжээний айлчпал хийсэн төдийгүй энэ айлчлапаар хоёр орны харилцааны асуудлыг тодруулсан "Упаанбаатарын тунхаглал" гаргасан нь айлчпалыг агуупгын хувьд улам баяжуупсан төдийгүй хоёр орны харилцааг "харьцангуй зогсонги" байдпаас гаргасан үйл явдал болсон.

Оросын хувьд хэт Өрнөд руү чиглэсэн бодлогоос Өрнө, Дорны бодлогоо тэнивэржүупэх чиг барьж эхэлсэн бодлогын хүрээнд Монгол улсыг Дорно зүгт гарах "гүур", өргөн уудам нутгаар хил залгаа байгаа хөрш, эртний сайн харипцаатай упс гэдэг талаас нь харж "Улаанбаатарын Тунхаглал" гарсан.

Энэ тунхаглап хоёр улсын харипцаанд гарсан улс төрийн анхны баримт бичиг туп давуу болон учир дутагдалтай талууд байсныг судпаачийн хувьд хэлж байгаа.

Ингээд Улаанбаатарын тунхагпал гарах энэ цаг үед хоёр орны дотоод упс төр, нийгэм эдийн засгийн нөхцөл байдал хэр байсныг товчпон харьцуупж үзэх нь зүйтэй.

\section{Монгоп упсын дотоод улс төрийн нехщелд байдап 2000 онд}

Монгоп улсын хувьд улс төрийн тогтолцоо нь 1993 оны Гэрээний уеийнхтэй адил байж 2000 оны УИХ-ын сонгуупийн дүнгээр байгуулагдсан парламент, засгийн газар нь үйл ажилпагаагаа явуупж байсан цаг үе байсан. 1997 оны Ерөнхийлөгчийн сонгуульд МАХНаас нэр дэвшин япапт байгуупсан Ерөнхийлөгч Н.Багабандийн бүрэн эрх хэрэгжээд 3 жил гаруй болж байсан ба 2000 оны парламентын сонгуулиар МАХН 72 суудап авч үнэмпэхүй олонхи болж, МҮАН, Монголын Шашинтны Ардчилсан Намын "Ардчипсан Холбоо" эвсэл, ИЗН, Ногоон Намын "Иргэний Зориг-Ногоон Нам" эвсэл, Эх Орон- МАШСН тус бүр 1 суудал авч, бие даагч 1 хүн сонгогджээ7. Олонхийн суудал авсан МАХН-ын дарга Н.Энхбаяр засгийн газраа эмхлэн байгуупаад 5 сар шахам болж байлаа. Эдийн засгийн нөхцөл байдал сайнгүй байсныг дараах статистик харуулж 
байна. 2000 оны байдлаар, ДНБ-ий өсөлт цөнгөж 1,1 хувьтай, нэг хунд ногдох ДНБ-ий хэмжээ 426,2 ам доппар, инфпячи 8,1 хувь, малын тоо толгой 30,2 сая, гадаад худалдааны апдагдал 78,7 сая ам долпар, ам доппарын ханш 1076,4 төгрөг, ДНБ-ий хэмжээ оны дүнгээр 1044 тэрбум төгрөг, гадаад валютын нөөц 160 сая ам доппар, төсвийн алдагдал -6,4 хувьтай байж ерөнхийдөө эдийн засгийн үзуупэлтүуд сайнгүй 9 байсан.

\section{ОХУ-ын дотоод улс төрийн нөхцеп байдап 2000 онд}

1999 оны 12 сард ерөнхийлөгч Б.Ельцин ажлаа Ерөнхий сайд В.Путинд шилжүүлэн өгч өөрийн "залгамжлагчаар" тодруулсан. Харин 2000 оны 3 сард болсон Ерөнхийлөгчийн сонгуульд В.Путин ялалт байгуупж 5 сард тангаргаа өргөн ажилдаа орсон. Өөрөөр хэлбэл, Ерөнхийлөгч Путин ажлаа аваад хагас жилийн дараа Монголд төрийн айлчлал хийжээ.

2000 он бол 1993 оны хоёр талын гэрээ байгуулах уеийг бодвол ОХУ-ын упс төрийн тогтолцоо тогтворжсон, эдийн засгийн нөхцөл харьцангуй сайжирч эхэлсэн цаг үе байлаа.

1999-2003 оны Төрийн Думд зуүний хүчин нийт суудпын 24 илуу хувьтай байсан ч төвийн хүчин болох "Единство", туүнийг дэмжсэн баруун төвийнхний нөлөө хучтэй байснаас энэ уед ерөнхийлөгчийн бодлого тууштай хэрэгжих таатай нөхцөл бурдсэн.

ОХУ-ын Төрийн Думын 1999 оны холимог системээр явагдсан сонгуупийн дүнгээр ОХУК-аaс 90 мандат, АПДГ-аас 39 мандат, Единство 82 мандат, Народный депутат бүлэг 59 мандат, OBP 45 мандат, Регион России 41 мандат, СПС 32 мандат, Яблоко 21 мандат, ПДПР 17 мандатыг тус тус авч Оросын парламентын доод танхим буюу хууль тогтоох дээд байгууплага байгуупагдсан байлаа.

ОХУ-ын эдийн засгийн зарим гол үзүулэлтүуд гэвэл дараах байдалтай байлаа. Үүнд: Гадаад өр 178,2 тэрбум ам доллар, валютын нөөц 19,8 тэрбум ам доллар, ДНБ 2003 оны үнээр 11217,3 тэрбум рубль, түүхий нефтийн экспорт 25,2719 тэрбум ам доллар, байгалийн хийн экспорт 16,6441 тэрбум ам доллар, 25 тэрбум ам долларын хөрөнгө зөвхөн 2000 онд гадагшаа гарсан ${ }^{9}$ байлаа.

\section{Тунхаглалын агуулгыг сийруүлбэл}

Ингээд Упаанбаатарын Тунхагпапыг дараах 4 зүйлээр агуулга талаас нь авч үзпээ. "Улаанбаатарын тунхаглап"- ын 25 зуйлийн 6 пункт нь эдийн засгийн агуупгатай байсан нь хоёр упсын харилцаанд ноёрхож байсан геостратегийн хуучин хандлага эдийн засгийн сонирхол давамгайлсан шинэ харилцаанд шилжиж буйг батпан 
харуупсан хэрэг байлаа. Энэ тунхагпал нь Монгол упсын хувьд чухал ач холбогдолтой хэдий ч тийм “чухал тунхаглал"-д тусгагдсан зарим эдийн засгийн асуудлыг зөвхөн хоёр аж ахуйн нэгжийн хооронд харилцан шийдэж болохоор байсныг судлаачийн хувьд миний бие "Улаанбаатарын тунхаглал түүний хувь заяа" ${ }^{10}$ өгуүпэлдээ 2002 онд тэмдэглэсэн.

\section{Упаанбаатарын тунхагпапын шүумжлэлтэй талууд}

ОХУ-ын бүс нутгийн байгууплага болох "Сибирское соглашение" -д ач холбогдол өгч хамтын ажилпагааг өргөжүүпэхийг баримт бичигт тунхагпасан хэдий ч энэ үйл ажиппагаа амжилт олоогүй буюу зохих ур дүнгээ өгсөнгүй.

Тунхагпалын 4-р зүйлд хоёр орны хоорондын төмөр замын хөнгөлөлттэй тариф, гаалийн татвар хураамж, худалдааг пиберапчлах, өргөжүупэх талаар тусгасан нь одоо хэр оновчтой шийдэгдээгүй бөгөөд ахиц дэвшил муутай байгаа. Энэ асуудап нь бараг хоорондоо худалдаа хийхгуй буюу худалдааны тэнцэл сөрөг дүнтэй хоёр улсын хооронд худапдааг пибералчпах гэдэг нь зүгээр нэг хоосон зүйлтэй зууралдахтай агаар нэг зуйл болсон.

Монгол, Орос, Хятадын гурван талын хүрээнд ачаа тээврийн асуудлыг боловсронгуй болгох ажлын талаар шинжээчдийн багийг үргэлжлуүпэн ажиллуупна хэмээн тохирсон ч ажлын үр гарсангүй ажил нь бараг зогссон. Гурван упсын дамжин өнгөрөх тээвэр нь зөвхөн төмөр замаар хязгаарлагдаж байгаа тул асуудиыг Хятадын төмөр зам, УБЖД хоорондоо яриад шийдэхээр боломжтой туп Тунхаглах зайлшгүй шаардлага алга байлаа. Улаанбаатарын тунхаглалд нэлээн хэдэн зүйлийг зөвхөн аж ахуйн нэгж, ведомства хоорондын хэмжээнд зохицуулахаар зүйлуүд байсан тухайлбал, 7 , 8, 9, 10-р пункт бүхэпдээ тийм байсан.

Тунхаглалын 15, 16-р зуйлд НҮБ-ын хүрээнд хамтран ажилпах, үйл түүний ажиллагааг дээшлүупэх, үр ашгийг нэмэгдүупэх, Мянганы хөгжлийн тунхагийн хүрээнд хамтран ажиллах гэх зэргээр хэвшмэл үг хэппэгээр асуудпыг томъёолсон байгаа нь хоёр орны харипцаанд байгаа буюу гарч болох асуудалд түлхуу анхаархыг орхигдуулсан зүйл болжээ. Ер нь ОХУ нь Монголын талаарх гомдлоо НҮБ-д өргөн бариад явахгүй нь нийтэд ойлгомжтой зүйл. Харин Монголын хувьд байж болох ч олон улсын хүчний харьцаанд өөрчлөлт гарсан өнөө үед НҮБ-ын үүрэг роль нэн шаардпагатай бус бөлгөө.

Упаанбаатарын тунхагпалын ач хопбогдоп бүхий ranyyd

Упаанбаатарын тунхагпап нь өнгөрсөн түухэн харипцааг 
хүндэтгэн, шинэ харилцааг баталгаажуупсан 1993 оны найрамдлын гэрээг бухэлд нь сайшаасан баримт бичиг байлда.

Улаанбаатарын тунхаглал нь ОХУ нь Монголтой зогсонги байсан харипцаагаа идэвхжуүпэх анхны алхам болсноороо ач холбогдолтой.

Тунхаглалд УБЖЛ-г сонирхсон тапууд Европ-Азийг холбосон тээврийн хэмжээнд ашиглахыг урьсан нь Монгол, Орост аль алиннд нь хэрэгтэй зүйл болсон.

Хоёр тал Үндэсний аюупгүй байдлын зөвлөлийн хүрээнд хамтран ажилпаж харилцаа хопбоог улам өргөжүупэхийг дэмжсэн явдал чухал зуйл байлаа. ОХУ нь дэлхийн упс төрийн нөлөө бүхий улс, цэрэг зэвсгийн боломж, техникийн хангамж, Монгол упсын аюулгүй байдлыг сахин хамгаалахал дэмжлэг үзуүиэх упсын хамтран ажиллах, хуучин хамтын ажиппагааг сэргээх чиглэлийг энд тунхагласан нь ач холбогдолтой болсон.

Тунхаглапын 13, 14-р зүйлд хоёр упсын хипийн асуудлыг онцгойлон тусгасан нь мөн чухал байлаа. Монгоп улсын цөмийн зэвсэггуй статусыг цөмийн зэвсэг бүхий таван упсын хамтарсан мэдэгдэлд гаргасан баталгаандаа ОХУ хэвээр гэдгээ дахин нотолсон ${ }^{11}$ байна. Түунд нь Монгол улс гун талархалтай байгаагаа ч ипэрхийпсэн.

ОХУ нь терроризм, хар тамхи, сепаратизм зэрэг асуудалтай тул Монгол улсыг энэ тал дээр бааз болгох аюул байгаа тиймээс энэ асуудлыг хөндсен Тунхагпалын 24-р зүйл нь ач холбогдолтой зүйл.

\section{Тунхаглапын үургээ гүйцэтгэсэн пунктууд}

Энэ тунхаглал нь Монгол-Оросын хооронд үуссэн Зөвлөлтийн Их өрийн асуудлыг зохистой шийдэхэд том алхам болсон бичиг баримт гэж үзэж болно.

Тунхаглапын 23-р зүйлд Монголын тал ШХАБ-ын зарим үйл ажилпагаанд сонирхлоо илэрхийпэн ямар хэлбэрээр оропцож болохоо мэдэгдсэн. Энэ үургийн хүрээнд Монгол упс 2001 оноос ШХАБ-ын ажигпагчийн статустай болсон. Тиймээс энэ пункт биепсэн гэж үзэж болно.

\section{Тунхагпапьн Үүргээ гүйцэтгээгүй пунктууд}

Тунхаглалын 5-р зуйлд дурдсан Зуүн Хойд Азид хэрэгжүүпж болох эрчим хүчний томоохон төспүүдэд хамтран ажиллах тал дээр хоёр талууд ач холбогдол өгсөн байдаг. Энэ нь нэгдүгээрт тухайн бүс нутгийн талаар дэлхий нийт хүпээн зөвшөөрсөн зүйл үгүй, хоёрдугаарт гэвэл эрчим хүчний төспуүд нь Монгопд ямар нэг хамааралгүйгээр хэрэгжээд эхэлсэн. Тухайн үед ОХУ нь Зүүн Азийн эрчим хүчний 
төсөлд Монгол упс эдийн засаг, газарзүйн байрлалын хүчин зуйлээрээ оролцохыг дэмжиж энэхүу Тунхагпапд оруупсан байлаа.

Зургадугаар пунк нь бүхэлдээ 2009, 2010 он хүртэл бүхэлдээ хэрэгжээгүй бөгөөд Москва, 2009 оны дээд хэмжээний уупзалтын дараагаар зарим нэг зүйп нь хөдөлгөөнд орсон.

\section{Тунхагпалын нийтэд ойлгомжгүй пунктууд}

Тунхагпалын 17-р зүйлд даяаршлын асуудалд талууд анхаарангаа, түүнээс үүдэн гарч буй упс орнуудын хоорондын хөгжлийн япгааг шинэ аюул хэмээн үзсэн. 18-р зүйлп Цөмийн зэвсгийг ул дэлгэрүүпэх Гэрээ, Цөмийн туршилтыг бүх нийтээр хоригпох Гэрээ, Химийн зэвсгийг хориглох Конвенцид бух упс орон нэгдэн орно гэдэгт талууд найдаж байгаагаа илэрхийлсэн нь Тунхагпапын энэ зүйлийг тун ч ойлгомжгүй байдалд оруупсан гэж дүгнэж болох юм.

Стратегийн давшилтын гэрээ-2 бүрэн утгаараа хүчин төгөлдөр болж хэрэгжих, Стратегийн давшилтын гэрээ -3 -г байгуулах нь цаашид цөмийн зэвсэглэлийг хорогдуупах үндэс суурь хэмээн томъёопсон нь өнөөгийн үнэнд ойлгомжгүй зүйлийн нэг болсон.

Зүүн Хойд Ази хэмээн упс төрийн хэппэгт хэвшмэл бопж чадаагуй бүс нутгийн нэр томъёог хэрэгпэхийн зэрэгцээ тэнд бух сувгаар яриа хэлэлцээрийн арга механизмыг идэвхижүупэхэд талууд онцгой анхаарсан нь эргэлзээ төруупэхуйц зүйл болсон.

Солонгосын хойгийн асуудал боп Монгоп,Орос хоёрт улс төрийн чухал ач холбогдоп бүхий зүйп тиймээс энэ талууд байр сууриа илэрхийлсэн нь сайн хэрэг. Гэхдээ энэ асуудпаар Талуудын байр суурьтай япгаатай туп нэг Декларачид ингэж ойлгомжгүй хэлбэрээр томъёолох нь буруу зүйл.

\section{4. Москвагийн Тунхаглап ${ }^{12}$}

Монгоп упсын Ерөнхийлөгчийн ОХУ-д хийсэн төрийн дээд хэмжээний айлчлалын үеэр буюу 2006 оны 12 сарын 8-нд Москва хотноо Монгол улс, ОХУ хамтарсан Москвагийн Тунхагпап гаргасан билээ. 2000 оны Улаанбаатарын Тунхаглапд тодорхой үнэлэлт дүгнэлт өгч, олон улсын бопон хоёр талын хооронд бий болсон зарчмын асуудиыг шийдэхэд түпхэц өгөх үуднээс талууд илүу нээлттэй, бүрэн итгэлцлийн түвшинд энэхүу Тунхаглалыг гаргасан.

Энэхуу Тунхаглап нь 1993 оны Гэрээ, 2000 оны Улаабаатарын Тунхагпап гарах уеийн хоёр орны улс төр, нийгэм эдийн засгийн байдал харьцангуй тогтворжсон, зарим талаараа сайжирсан цаг үед болсноороо онц/ог юм. 


\section{Монгоп упсын упс төрийн дотөод нөхцөп байдал}

Монгол упсын төр, нийгэм эдийн засгийн нөхцөл байдал хуупь эрхзүйн хувьд хэвийн буюу 2000 оны УБ-ын Тунхагпалын үеийнхтэй адип төстэй байсан хэдий ч 2004 оны парпаментын сонгуупьд МАХН 36, Ардчилсан Нам, Эх Орон Намын "Эх орон-Ардчилап" эвсэл 36,БНН 1 суудал авч, Ардчилсан Намын 3 гишүун бие даан нэр дэвшиж сонгогдож 2006 он гэхэд 2 Засгийн газрын байгуулсан $\mathrm{ye}^{13}$ байлаа. Ерөнхий сайд Ц.Элбэгдоржийн Эвспийн засгийн газар огцорч ерөнхий сайд М.Энхболдын Үндэсний эв нэгдлийн засгийн газар байгуулагдсан уе байсан. 2005 оны Ерөнхийлөгчийн сонгуульд МАХН-аас нэр дэвшсэн Н.Энхбаяр бурэн эрхээ хэрэгжүүпээд 1 жил болж байлаа. Нийгэм эдийн засгийн гол үзуүпэлтууд дараахи түвшинд байлаа. 2006 оны байдлаар, ДНБ-ий өсөлт дөнгөж 8,6 хувьтай, нэг хүнд ногдох ДНБ-ий хэмжээ 998 ам долиар, инфпяци 6,2 хувь, малын тоо толгой 34,8 сая, гадаад худалдаа 107 сая ам доппарын ашигтай, ам доппарын ханш 1165 төгрөг, ДНБ-ий хэмжээ оны дүнгээр 1044 тэрбум төгрөг, гадаад валютын нөөц 687,25 сая ам долпар, улсын төсөв 3,1 хувийн ашигтай гарсан ерөнхийдөө эдийн засгийн үзуүпэлтүуд сайжирч ${ }^{14}$ байсан.

\section{ОХУ-ын упс төрийн дотоод нөхцөл байдал}

ОХУ-ын Ерөнхийлөгч В.Путины 2 дахь бүрэн эрхийн хугацаа хэрэгжээд 2 жил гаруй болж байсан ба Оросын 2003 оны Төрийн Думын сонгуульд улс төрийн 4 хүчин дараахи тооны мандаттай бопжээ. Үүнд: Единая Россия- 223 мандат (120/103), КПРФ52 (40/12), Родина - 37 (29/8), ПДПР - 36 (36/0), НПРФ - 17 (0/17).

Ерөнхийлөгчийн засаглалыг хүчтэй болгох ууднээс упс төрийн томоохон өөрчпөпт явуупсан нь упсын хэмжээний бопон субъектуудын улс төрийн үйл явцыг үндсээр өөрчипсөн. Үүнд: субъектуудын хууль тогтоох байгууппагуудын депутатуудын 50-аас доошгүй хувийг сонгуупийн пропорциональ системээр зайлшгүй явуулах заалт, Холбооны Зөвлөл буюу Оросын парламентын дээд танхимыг бүрдуупэх журамд өөрчпөлт оруулж, тэндээс субъектуудын амбан захирагч, хурлын дарга нарыг гаргасан, субъектуудад сонгуупийн өмнөх эвсэл, улс төрийн намууд байхыг хоригпосон, амбан захирагч нарыг сонгуулиар бус дээрээс томилдог болгосон, намын нэрээр сонгогдох босгыг алгуур өндөрсгөв.

Барууны болон баруун төвийн чиглэлтэй улс төрийн хүчнүүдийн байр суурь суларч, центрист, зүүн болон зүун төвийн улс төрийн хүчнүүдийн байр суурийн бэхжипт хучтэй ерөнхийлөгийн 
засаглапыг улам бэхжуүпсэн. 2001 онд батпагдаж, 2006 онд шинэчпэгдсэн "Упс төрийн намуудын тухай" хуупиар тэдгээрийг "цэгцлэх" бодиогыг явуупж байна. Улс төрийн намуудын хэмжээнд ОКН, ПАН хоёр $п$ төлөвшөөд байгаа.

2006 оны байдлаар ОХУ-ын эдийн засгийн нөхуөл байдлыг тоймолбол.

Гадаад өр 257,2 тэрбум ам долпар, валютын нөөц 237,5 тэрбум ам доллар, ДНБ 2003 оны үнээр 16286,5? тэрбум ам. долпар, түүхий нефтийн экспорт 102,2829 тэрбум ам доплар, байгалийн хийн экспорт 43,8062 тэрбум ам доллар, зөвхөн 2006 онд гэхэд гаднаас 41,6 тэрбум ам допларын хөрөнгө орж ирсэн ${ }^{15}$ байлаа.

\section{Тунхаглапын ач хопбогдоп бүхий пунктууд}

1993 оны Гэрээндээ талууд үнэнчээ дахин нотолсон. 2003 онд Монгол, Оросын хоорондын шилжих рублийн өрийн асуудпыг зохицуулсан явдлыг цаашид хоёр орны хоорондын харилцааг бүх талаар өргөжүупэх шинэ боломжийг бий болголоо хэмээн талууд сэтгэл хангалуун тэмдэгпэсэн.

Тапууд эдийн засгийн опон сапбарт тухайлбал, түпш эрчим хүч, геологи ууп уурхай, тээвэр, хөдөө аж ахуй, банк санхүүгийн салбарууд, түүнчлэн олон улсын стандарт, эдийн засгийн бодит нөхцөлд нийцсэн хамтарсан төспүүдийг хэрэгжүүпэх нь зайлшгүй чухал гэдэгт санал нийлсэн байна.

АПЕК-д Монгоп улсыг элсэхэд ОХУ дэмжлэг үзуүпэхээ илэрхийлсэн явдал манайд чухал зүйл болно.

\section{Тунхаглалын шүүмжлэлтэй пунктууд}

Энэ баримт бичигт дээд хэмжээний айлчлалын явцад хоёр талаас гарын үсэг зурсан 8 санамж бичиг, гэрээний тухай ердийн протоколын шинжтэй зүйлийг нэг бүрчпэн бичсэн явдал байлаа.

Харипцан хөрөнгө оруупалт, худапдааг өргөжүүпэх, таатай орчинг бурдуупэх тал дээр хуупийн хурээнд тапууд хамтран хучин чармайлт гаргах ёстой гэдэг дээр нэгдмэл байлаа хэмээн тунхагласан явдал бол хууль нь ийм байдлыг бий болгоход төвөгтэй хэлбэрээр батлагдсан тул асуудал дагуулсан зүйл юм.

Монгол-Оросын засгийн газар хоорондын комисс нь уйл ажиллагааны хувьд тогтмолжсон хэдий ч хоёр орны хамтын ажиллагааг системтэй төлөвлөгөөтэй тууштай урагшлуупах тал дээр дорвитой ажип хийхгүй байгааг талууд сайн ажил хийж байгаа хэмээн дугнэж байгаа нь учир дутагдалтай зүйл.

Хоёр талын хамтарсан үйлдвэр аж ахуйн газруудын техникийн шинэчпэл, удирдпагыг чадваржуулах, хөрөнгө оруулаптын төспийг 
хэрэгжуупэх замаар хучин чадиыг нэмэгдуүпэхэд сонирхоптой байгаагаа тапууд батапсан хэмээн тунхаглахаас илуу тэдгээр аж ахуйн нэгжуудийг бизнесийн горимд шилжуупэх тал дээр анхаарах чухал байлаа.

УБЖД асуудлаар тапууд өргөжуупэх, хөгжүупэх, шинэчлэх нь чухап гэдгийг тэмдэглэсэн ба туүний суурь гэрээг шинэчлэнэ гэж тодруупсан байдаг. УБЖД хувьд 1949 оны гэрээг шинэчлэхээс асуудал эхлэх ёстой гэдгийг талууд шууд хүпээн зөвшөөрөхгуй байгаа нь учир дутагдаптай зуйл.

Иргэдийн харилцан зорчих асуудлыг хөнгөвчлөх талаар талууд санал нэгдсэн хэдий ч энэ асуудал опон жилээр шийдэгдээгүй байна. Хөвсгөл, Байгал нуур дамнасан аялал жуупчлал хөгжуүлэх асуудлыг аж ахуйн нэгж хоорондын хэмжээнд шийдэх асуудал билээ.

\section{Тунхагпалын уүргээ гүйцэтгэсэн пунктууд}

Хоёр тал боловсрол, соёл, аялал жуулчлал, хүмүүнлэгийн сапбар дахь хамтын ажиппагааг улам идэвхжуупэх, агуулгыг сайжруулах талаар санаачилга гаргаж энэ тунхаглалд илуу тод томруун тусгасан явдал Москвагийн Тунхаглалын агуупгыг баяжуупсан явдал болжээ.

Талууд ажилпах хүчний шилжилт хөдөлгөөний талаар Тунхаглапд тусгасан нь өнөөгийн ажипгүйдиийн нөхцөлд зөв зүйтэй асуудал бопсон.

Батлан хамгаалах болон хүчний байгууплагын болон Аюупгүй байдлын хамтын ажилпагааг илуү оновчтой, харилцан ач холбогдолтой болгох талаар талууд санаачилга гаргасан зүйл нь Үүргээ сайн гүйцэтгэж буй зүйл хэмээн узэх үндэстэй.

Бүс нутгийн болон олон улсын асуудлаар ОХУ-тай адип төстэй байр суурьтай гэдгээ Монгоп улс тунхагласан нь чухап зуйл. Хоёр улс тогтвортой хөгжлийг хангах уүднээс өөр хоорондоо болон сонирхсон талуудтай хамтын ажиллагааг өргөжүулэхэд бэлэн гэдгээ Тунхагласан нь чухал ач хопбогдоптой зуйл бипээ.

Дэлхий дахины соёл иргэншлийн олон хэпбэрийг хундэтгэн үзэж улс бүрийн хөгжлийн бие даасан тусгаар сонголтыг талууд хүпээн зөвшөөрсөн нь ач хопбогдоптой зүйл. Олон улсын аливаа хямралыг шийдэхэд оролцог талуудын хууль ёсны сонирхлын дагуу олон улсын эрхзуйн хэм хэмжээнд улс төр-дипломатын аргаар зохицуупахыг талууд тэргүун зэрэгт тавьсан нь зүйтэй.

Монгол упсын аюупгүй байдпын баталгааг гаргасан цөмийн зэвсэг бухий таван упсын хамтарсан мэдэгдпийг ОХУ сахин хангана гэдэгтээ үнэнчээ дахин нотолсон явдал чухал зуйл байлаа. 


\section{Тунхаглалын Үүргээ гүйцэтгээгүй буюу орхигдсон}

\section{пунктууд}

Тунхаглалд ШХАБ-ын талаарх хоёр талын байр суурийг ипүу оновчтой, ойлгомжтой хэпбэрээр тусгах нь ажиглагчийн хүрээнд Монгол улс ШХАБ-ын жөорондын цаашдын хамтын ажилпагааг ойлгомжтой болгох байлаа. ШХАБ-ын хүрээнд хамтын ажиллагааны тэргүүпэх салбар дахь хамтын ажиллагааг нээлттэй, харилцан ашигтай хэлбэрт шипжүупэн гишүуд, ажиглагчийн оропцооны хувь хэмжээг тодорхой бус байгаа өнөө уед үйл ажиллагааг идэвхжүупэх талаар талууд тусгасан нь энэ Тунхагпалын хувьд үүргээ гүйцэтгээгүй зүйл болноо.

Евразийн эдийн засгийн хамтын нийгэмпэгт Монгоп упс элсэх боломжийн талаар судалж байгаа гэдгээ Монголын тал мэдээлсэн явдал нь "асуудал" дагуупсан зүйл болсон байна.

\section{Тунхаглалын нийтэд ойлгомжгүй пунктууд}

Монгол-Оросын хоорондын гадаад худалдааны алдагдал 1 тэрбум ам доппар гараад байхад талууд цаашид худапдаа, эдийн засгийн хамтын ажиппагааг өргөжүупэх тал дээр харилцан хүчин чармайлт гаргана хэмээн заасан нь тун ойлгомжгүй зүйл. Улаанбаатарын Тунхаглалд тусгасан нэг апдаа буюу Зүүн Хойд Азийн бүс нутаг гэсэн нэр томъёог дахин ашиглан тэнд хамтын ажиллагааг өргөжүүпнэ хэмээн тунхагпасан нь ойлгомжгүй байдалд оруупж байна.

\section{ДУГНЭЛТ}

Монгол, Оросын хоорондын найрамдал, хамтын ажиллагааны гэрээ нь хоёр орны харипцааг шилжилтийн үед төдийгүй зах зээлийн харипцааны өнөөгй̆н нөхцөлд, опон упсын харилцааны шинэ уе орчинд зохинуупж буй баримт бичиг.

1991 оны Хамтын ажилпагааны Тунхаглапд оролцсон ЗСБНХОУ нь 8 сарын дараа ОХУ хэмээн нэрлэгдэх болсон бол БНМАУ нь нэг жипийн дараа Монгол упс хэмээн нэрпэгдэв. Хэдийгээр гэрээнд оролцсон субъектуудын улс төр, нийгэм, эдийн засгийн бодлогын хувьд эрс өөрчпөгдсөн ч гадаад харилцааны залгамж чанар хадгалагдан үлдэж хоёр хөршийн хооронд байгуулсан Тунхаглапд өөрчлөлт ороогүй болно.

1990-ээд оны эхээр Орост ард иргэдийн дунд “не мы содержим государство, а оно нас обязано кормить, финансировать и одевать" гэсэн ойлгопт хүчтэй байсан бол Монгопд "төр упсаа харахаа болъёо, өөрсдөө аргаа бодохоос гэсэн ойлголттойгоор 
хун гадаад паспорт өвөртпөн ганзагын наймаанд мордсон". Харин нэлээн хожуу Монгопчуудын дунд "төр бүхнийг хийх ёстой гэсэн тэжээвэр санаа газар авсан" нь оросуудын 1990 оны эхээр баримталж байсан ойлголттой ойролцоо болж эхэлсэн.

Олон улсын улс төр, эдийн засгийн нөхцөл эрс өөрчлөгдөж хүчний харьцаа өөрчлөгдсөн цаг уед урьдын ижил ашиг сонирхол үгүй болсон, өөрсдийн эрх ашгаа өөрсдөе тодорхойлсон, улс төрийн ондоо тогтолцоо, эдийн засгийн өөр хүч чадалтай, нийгэм эдийн засгийн шийдвэрлэх асуудлын далайцаар эрс өөр, соёл, амьжиргааны ахуй өөр, газарзүйн байрлалын хувьд мөнхийн хөрш, өмнөх системд улс төр, үзэл суртап, нийгэм эдийн засгийн хувьд хамгийн ойр дотно холбоотон байсан зэрэг хоёр орны хамтын ажиллагааг баталгаажуулсан баримт бичиг юм.

1991 оны гэрээ байгуупах уед болон 1993 оны Гэрээг байгуулах уеийн олон улсын нөхцөп байдлын талаар судлан тогтоох нь Гэрээний бодит байдалд чухал зүйл. Иймээс 1991 оны 2 сард байгуупсан сайн хөршийн тунхаглапд олон улсын байдап хэр нөлөөлсөн талаар дурдах нь зүйтэй. Олон упсын хэмжээнд сөргөлдөгч талууд үгүй болж, эвсэл болон тэмцэлдэгчид ерөнхийдөө нэгэн том эвсэпд түр зуур ч гэсэн хамаарах болсон.

1991 оны Тунхаглал, 1993 оны Гэрээнд 1921 оны найрамдал хамтын ажилпагааны гэрээг хоёр орны хамтын ажиллагаанд чухал Үүрэг гүйцэтгэсэн хэмээн тэмдэгпэсэн байна.

1991, 1993 оны Тунхаглал, гэрээнд хоёр тал эдийн засгийн нээлттэй бодлогыг харилцан дэмжих, харилцан үр ашигтай хамтын ажиллагааг хөгжуүпэх, туунд таарсан нөхцлийг бурдуулэх уурэг хупээсэн ба хамтарсан үйлдвэр аж ахуйн газар байгуулж, түүнд гуравдагч улсаас түнш оропцохыг хөхиулэн дэмжинэ хэмээн тунхаглан баталгаажуупсан.

1991 оны Тунхагпалд БНМАУ-ыг Төв Ази, Ази Номхон далайн бүсэд хамруулан үзэж байсан бол 1993 онд Монгоп упсыг Ази Номхон далайн бүсэд хамруупах болсон.

1990-91 онууд Монголд намын хүчин зүйл хүчтэй болж, Орост пидер удирдагчийн хүчин зуйл хүчтэй болсон цаг мөч байлаа.

Монгол угсааны олон улс ОХУ-д аж төрдөг тул монголын язгуур эрх ашиг бол ОХУ-тай бух талаар ойртон хамтран ажиллах нь чухал.

Гадаад улс орнуудтай гэрээ, хэлэлцээрийг хийхдээ тухайн гэрээг байгуупж буй субъектууд хэр эрхзуйн чадамжтай эсэх, улс оронд хэрэгжиж буй хуупь эрхзуйн актуудтай нийцэж буй эсэх, 
ерөнхийдөө талуудын сонирхлыг бүрэн илэрхийпж байгаа эсэх зэрэг бичигдсэн болон “бичигдээгүй” хуулиудыг хэр авч үзсэн зэрэг олон асуудлыг цаашид анхаарч байх уүднээс энэхуу судалгааны өгүупэл бичигдсэн бопно.

ОХУ-ын Еренхийлөгч В.В.Путин 2000 онд Монголд хийсэн айлчпалын уеэр “Орос-Монголын харилчааг урьдах түвшинд сэргээх нь бидний гол зорилт" 16 хэмээн тодорхойлсон.

Улаанбаатар, Москвагийн Тунхаглал нь ОХУ-ын Ерөнхийлөгч В.Путины 2 бүрэн эрхийн хугацаанд хийгдсэн баримт бичиг. ОХУ нь Ерөнхийлөгчийн хамгийн өргөн эрх мэдэлтэй БНУ. Өнөөгийн ОХУ-ын улс төрийн систем нь хуучин Зөвлөлтийн бурэлдэхуунд байсан бараг бух БНУ-уудад давтагдаж байгаа систем.

Хэдийгээр Монгол, Оросын хооронд стратегийн түншлэлийн тапаархи гэрээ хэпэпцээрийн баримт бичгүуд нь бүгд хуупь эрх зүйн чадамжтай байсан хэдий ч энэхуү судалгаагаар аливаа гэрээ, хэлэлцээрийн пегитимность нь хэр вэ гэдэг онцгой анхаарах нь чухал гэсэн дүгнэлт хийж байна. Нэн ялангуяа, улс төр, эдийн засгийн чадавхи суп орнуудад энэ нь он山гой чухап бөлгөө.

\section{ЭШ/ЭЛ, ЗYҮ}

${ }^{1}$ Ц.Майдар. Нэн шинэхэн түух. 1991, УБ., х.32-41

${ }^{2}$ Мөн тэнд

${ }^{3}$ Монгол-Оросын харилцаа баримт бичиг 1991-2004. УБ., 2006. T.24.

${ }^{4}$ www.gec.gov.mn

5 OYC, 2002 oн, дyraap 2.

${ }^{6}$ Монгоп-Оросын харипцаа баримт бичиг 1991-2004. УБ., 2006. T.24-28

${ }^{7}$ www.gec.gov.mn

8 "Монгоп упс зах зээлд" статистикийн эмхэтгэл, 19892002он, хуудас 92-229,

${ }^{9}$ на официальном сайте Банка России http://www.cbr.ru

${ }^{10}$ Восток и Россия:взгпяд из Сибири.Материалы и тез.докл.к науч.-практ.Конф.-Иркутск, 2002.N•105-116.

${ }_{11}$ Монгол-Оросын харипцаа баримт бичиг 1991-2004. УБ., 2006. T. $160-166$

12 wrw.mongolia.mid.ru

${ }^{13}$ www.gec.gov.mn

14 Үндэсний статистикийн хорооны эмхэтгэп. 2012 он, хуудас 126-182. 
15 на официальном сайте Банка России http://www.cbr.ru 16 14.11.2000 9:44 । PБK

\begin{abstract}
:
This research work considers detailed investigation of the following four important documents, which were signed between Mongolia and Russia after 1991. These are "The declaration of friendship and cooperation", "The agreement of friendship, cooperation and neighbourly relationship between Mongolia and Russia", "The declaration of Ulaanbaatar", "The declaration of Moscow". The research briefly compares economic and political environment in both countries during times when these documents were formed. Furthermore, this research work evaluates these important documents which play a profound role in strategic partnership between Russia and Mongolia.
\end{abstract}

Keywords: Mongolia, Russia, Declaration of Ulaanbaatar, Declaration of Moscow, Mongolian and Russian agreement of 1993, Declaration of friendship and cooperation between Mongolia and Russia. 